https://helda.helsinki.fi

\title{
Semiotics of Translation, Translation in Semiotics
}

\section{Kukkonen, Pirjo Liisa Helinä}

2015

Kukkonen , P L H \& Kourdis , E (ed.) 2015 , ' Semiotics of Translation, Translation in

Semiotics ' , Punctum.International journal of semiotics , vol. 1 , no. 2 , 1 , pp. 5-10 . https://doi.org/10.18680/hss.201

http://hdl.handle.net/10138/228363

https://doi.org/10.18680/hss.2015.0012

cc_by_nc_nd

publishedVersion

Downloaded from Helda, University of Helsinki institutional repository.

This is an electronic reprint of the original article.

This reprint may differ from the original in pagination and typographic detail.

Please cite the original version. 


\title{
INTRODUCTION Semiotics of translation, translation in semiotics
}

\author{
Evangelos Kourdis and Pirjo Kukkonen
}

The object of this special issue of Punctum, devoted on Semiotics of Translation, Translation in Semiotics, is the potential of interaction between the semiotics of translation and semiotically-informed translation studies. It sets out to explore the dimension of translation studies as an interdisciplinary endeavor and bring together scholars of translation and semiotics.

The contact between the two disciplines dates back to the late 1950s, when the linguist and semiologist Roman Jakobson presented his position on the three modes of translation: intralingual, interlingual and intersemiotic (Jakobson 1959). As to the first two types of translation, the history of translation studies has much to offer. The introduction of a new research field in translation studies - that of intersemiotic translation - at a time when the research field of semiotics was not yet entrenched, but was in a state of constant quest, caused both surprise and skepticism to those involved in translation studies. As Hermans observes:

Looking at the essay from today's vantage point, we can also appreciate it both as being part of the self-description and self-reflexiveness of translation, in questioning precisely the boundaries of the field and thus engaging in the discussion about what is and what is not translation, what falls inside or outside, and as being part of an emerging academic discipline of translation studies. (Hermans 1998: 25)

The publication of Jakobson's seminal paper occurred in an era in which translation studies was not a fully recognized field in the humanities - there are some translation scholars who believe that translation studies still do not have this recognition. This is the case because 'during the sixties semiotics was dominated by a dangerous verbo-centric dogmatism whereby the dignity of language was only conferred on systems ruled by a double articulation' (Eco 1976: 228) and translation studies focused on the nature of the signifier, prioritizating the linguistic dimension of the translation process. Translation studies was not seen as an autonomous discipline and was under the umbrella of the philological, or at best, the linguistic approach to communication.

More specifically, structural linguistics dominated Europe and was trying to change the deeply rooted belief that Ferdinand de Saussure's parole or Algirdas-Julien Greimas's process or Roman Jakobson's message were not subjects worthy of scientific study. The main assumptions of structuralism and semiology (or semiotics) would be that for every process (an utterance, for instance) there is a system of underlying rules that govern it, and that the system arises contingently.

And if parole is not worth studying, is the image worth studying? Can the image have rules? Roland Barthes' celebrated study La rhétorique de l'image (1964), among the first semiological studies of advertising, influenced desicively the way the scientific community approached the image. Although Barthes did not connect the image with translation, he contributed in establishing it as an object of study, next 
to that of linguistics, by uncovering the structural composition of the visual message, something that was later confirmed by the work of Groupe $\mu$ (1992). That led the way to the study of the transformation of semiotic systems. Researchers could thus approach the case of untranslatability and information loss in the translation process from a new perspective. Terms like equivalence, negotiation, mediation formed the basis for a new dynamic branch of the human sciences, that of translation studies.

The boundaries of the translation process, therefore, had been expanded quite early by the semioticians, something which that was not acknowledged by translation scholars, who perceived their approach as being primarily metaphorical. Nonetheless, everyday life teaches us not to approach the field of semiotics metaphorically. Umberto Eco observes that:

[c]ulture continuously translates signs into signs, and definitions into definitions, words into icons, icons into ostensive signs, ostensive signs into new definitions, new definitions into propositional functions, propositional functions into exemplifying sentences, and so on; in this way it proposes to its members an uninterrupted chain of cultural units, and thus translating and explaining them. (Eco 1976: 71)

Susan Petrilli and Augusto Ponzio also argue that:

[t]he translator must navigate in the iconic dimension of language and move beyond the conventions and obligations of the dictionary to enter the live dialogue among national languages, among languages internal to a given national language, and among verbal signs and nonverbal signs. (Petrilli and Ponzio 2012: 20)

Eco, Petrilli, Ponzio, and many others distinguished semioticians point to the continuous transition of the translator from one cultural text to the other, to cultural translation. This is a field in which the Tartu-Moscow School and the emblematic figure of Juri Lotman have contributed greatly. In an era of multisemiotic and multimodal communication, in which meaning is continuously transformed among different semiotic systems and intermedially, who could disagree with Lotman's position (1990: 271) that 'the instrument of semiotic research is translation'. Indeed, the most important contribution of the Tartu-Moscow School is the correlation of the concept of culture with the concept of translation, the recognition that culture works in many respects as a translation mechanism. As Torop (2008: 256) notes ' $[\mathrm{t}$ ] ranslation semiotics itself can be regarded as a discipline that deals with mediation processes between various sign systems, and, on the macro level, with culture as a translation mechanism'.

Gradually, however, the scepticism of translation scholars abated and there were calls for drawing on semiotics to enrich translation theory (Stecconi 2009: 261). As early as the 1980s, translation scholars started to timidly turn to semiotics. Thus, for Bassnett (1980: 13), "[t]he first step towards an examination of the processes of translation must be to accept that although translation has a central core of linguistic activity, it belongs most properly to semiotics [...]'. Basil Hatim and lan Mason (1990: 133-137) discuss genre, discourse, and intertextuality within the framework of semiotics and ideology and maintain that semiotics can hope to offer something to translators, interpreters and indeed all those who work with language. Mona Baker also considers that translation by illustration (intersemiotic translation):

is a useful option if the word which lacks an equivalent in the target language refers to a physical entity which can be illustrated, particularly if there are restrictions on space and if the text has to remain short, concise, and to the point. (Baker 1992: 42)

What is the reason for this gradual shift? Translation scholars, such as Jeremy Munday (2004: 216), argue that 'translation studies must move beyond the written word and that the visual, and multimodal in general, must be incorporated into a fuller study of the translation of advertising'. The expansion of the translation process to include non-verbal texts caused debate about the na- 
ture of translation, although there seems to be an agreement that contemporary communication is based almost exclusively on multimodal texts, as there is an "[...] incessant process of "translation", or "transcoding" - transduction - between a range of semiotic modes [that] represents, we suggest, a better, a more adequate understanding of representation and communication' (Kress and van Leeuwen 2006 [1996]: 39).

The articles included in this volume reflect the way semiotics influences translation studies, broadening not only the notion of translation but also the field of translation studies. The volume concentrates on both theoretical and applied contributions: intersemiotic translation, multimodal translation, translation semiotics, audiovisual translation, retro-translation, anthropological translation, interpretative semiotics.

Daniella Aguiar, Pedro Atã and João Queiroz in their article 'Intersemiotic translation and transformational creativity' approach a case of intersemiotic translation as a paradigmatic example of Boden's 'transformational creativity' category. To develop their argument, they consider Boden's fundamental notion of 'conceptual space' as a regular pattern of semiotic action, or 'habit' (sensu Peirce). They exemplify with Gertrude Stein's intersemiotic translation of Cézanne and Picasso's proto-cubist and cubist paintings. The results of Stein's IT transform the conceptual space of modern literature, leading it towards new patterns of semiosis. Their application of Boden's framework to describe a cognitive creative phenomenon with a philosophically robust theory of meaning results in a cognitive semiotic account of intersemiotic translation.

The authors' purpose is to present a model of IT based on Peirce's pragmatic philosophy of signs. They argue that IT phenomena should not be dissociated from a general theory of the sign, which provides a general model of semiotic processes and a classification of semiotic morphological variety. Moreover, if a creative translation is the most attentive way of reading a sign system or a text, then an IT can be considered an even more radical practice, since it is obliged to 'transcreate' the same effects produced by the source using drastically different systems and materials.

George Damaskinidis in his article 'Mediating between verbal and visual semiotic elements in the translation of English multimodal texts into Greek' examines the relation of verbal to visual semiotic elements, and proposes a mediation-based codification for intersemiotic translation. Using the concept of translation mediation, he proposes a verbo-visual mediated approach to translation, whereby both the verbal and the visual are potentially considered as translation factors. His approach employs social semiotics and multimodality for the empirical investigation of the translation of multimodal texts. By way of illustration, he provides the Greek translation of an English print advertisement, which is discussed and codified using degrees of verbo-visual mediation.

Multimodality and multisemiosis is a growing field of research. In recent decades we find more and more articles relating multimodality with translation studies, taking into consideration that nowadays there is no monosemiotic text. It is worth mentioning that although translation studies welcomes approaches to translation through the lens of multimodality, some semioticians hesitate to adopt this approach. It is true that the theoretical semiotic background of multimodality, at least as it is described in the works of Gunther Kress and Theo van Leeuwen (2001, 2006 [1996]), is not essentially contested. What seems to be contested is the actual application of the multimodality theory, as well as their claim of offering a visual grammar. The fact that we welcome contributions concerning multimodality to this volume on translation semiotics reflects our belief that this approach can act as a bridge between semiotics and translation studies.

Ritva Hartama-Heinonen in her article 'Herding together: On semiotic-translational branches, fields, and disciplines' focuses on the essence of disciplinary fields and boundaries, and puts forward the question whether semiotic translation research constitutes a field within which researchers understand each other and share the world of research both theoretically and methodologically. For Hartama-Heinonen, semiotic approaches to translation can be divided into two groups: they contribute either to the Semiotics of translation or to semiotic Translation Studies. 
The former, semiotic-bound field takes as its domain what Roman Jakobson (1959) called the three ways of interpreting verbal signs, namely, intralingual, interlingual, and intersemiotic translation. The crucial and pioneering aspect of Jakobson's approach was whether the sign systems involved in a translation are verbal or non-verbal. The latter, which has its home within Translation Studies, seems (more or less afterwards) to have found Jakobson applicable in the new intralingual forms of translation (e.g. print interpreting) or in those intersemiotic ones which, as Mary Snell-Hornby (2006) describes them, reach 'beyond language', exemplified by researchers' growing interest in phenomena of a multimodal or multicodal nature. Hartama-Heinonen concludes her article with a simple but crucial question: who owns translation, and who owns semiotics? Who owns Jakobson? She thus underlines the fact that Jakobson's work was the result of the interaction of three humanistic disciplines: linguistics, semiotics, and translation.

Loukia Kostopoulou in her article 'Translating culture-specific items in films: the case of interlingual and intersemiotic translation' examines the specificity of film as a medium in which the translator mediates between languages and cultures. The research is based on the examination of culture-specific items in French and Greek films and their subtitles. In subtitling, non-verbal messages play an important role in the process of communication. In the frequent cases where the verbal message cannot be easily rendered, the visual message can be used to cover this gap. She also explores whether the spatiotemporal constraints of subtitling allow the viewer to understand the meaning of culture-specific items or not. Her research focuses on both visual and verbal messages, since culture-specific items often need to be localized in order to be better perceived by the target language community.

Most studies of subtitling focus on the semiotic system of language, and the intersemiotic dimension, although it is part of semiosis, is not explored. Kostopoulou aptly explains that the doubling of the visual and the verbal in subtitling implies intersemiosis, considering that we are dealing with an occasionally partial verbalization of non-verbal signs in order to achieve cohesion. As Díaz-Cintas and Remael (2007: 171) argue, 'intersemiotic cohesion in subtitling refers to the way it connects language directly to the soundtrack and to images on screen, making use of the information they supply to create a coherent linguistic-visual whole'.

René Lemieux in his article 'Retour de Babel: l'indécidabilité derridienne et la rétrotraduction en supplément' attempts a critique of Lawerence Venuti's commentary on his translation of a lecture by Derrida on translation. The text poses the question of the division in language which translation seems to bring about. This division between the original and the translated text is treated in the first part through a reflection on 'name' and 'naming' in the myth of the tower of Babel. The second part is an analysis of the difficulties of translating into English the works of Jacques Derrida, as attempted by Lawrence Venuti, and of a comment on this process in English by Venuti himself, which was then translated into French. The whole process of translating and back-translating (retro-traduction) reveals one of the common traits shared both by the act of translating and deconstructive thinking. Both necessitate a kind of 'surplus of language', which has crucial implications both for the theory of translation and for its semiotic description.

Massimo Leone's article 'Anthropological translation: A semiotic definition' concerns the quest of adequate verbalization of unexpressed semantic lines in one's culture before being able to convey them into another language and culture. After proposing a theory of language inspired by the Danish linguist Louis T. Hjelmslev, the essay articulates a typology of translation tasks, divided according to the conceptual difficulty that they entail. The hardest but also the most revealing kind of translation, Leone argues, is anthropological translation. This he exemplifies by examining a series of intercultural accidents resulting from Dante's depiction of the prophet Mohammad in the Divine Comedy. Anthropological translation, it is argued, allows one to reframe such conflicts and to subsume them at a superior level of understanding.

This connection between translation and anthropology should not surprise us, since both disciplines involve a search for interpretation. Indeed, for social anthropologists such as Larsen (1987: 1), 
the problem of translation seems to be 'anthropology's most important theoretical problem'. As Pálsson (1994: 1) states '[...] if there is a root metaphor, which unites different ethnographic paradigms and different schools of anthropological thought, it is the metaphor of cultural translation'. Pálsson adds that "[a]nthropologists are presented as semiotic tour guides, escorting alien "readers" in rough semiotic space'. The representation of Mohammad in the Commedia is such a rough semiotic space, which demands the intricate interpretative labor of anthropological translation.

Susan Petrilli in her article 'Translation of semiotics into translation theory, and vice versa' claims that reflection on sign processes and reflection on translation processes can help each other to better identify the problems that concern them respectively, and orient their specific methodologies, since they study the same processes: the relation between a sign and another sign, which in the role of interpretant confers a given meaning and sense on the preceding sign. To study this relationship means to become aware of its dialogical character. Therefore, as much as the disciplinary spheres may be different, the theory - or science - of signs, semiotics, and translation theory study the same process, semiosis. For Petrilli, semiotics and translation may act as interpretants of each other and thus illuminate different aspects of the signs forming the process itself, underlining at once their specificity and interrelatedness. Petrilli claims that to translate is to recreate, to create the conditions for the text to live its life fully, to free it from the limits of language and contemporaneity.

Semiosis, otherness, dialogism, responsive understanding, similarity are some of the key notions explored by Petrilli in her article. Derived from Peirce and Bakhtin, these are notions that continue to engage semiotic theory, but translation studies have only recently started to approach. Peirce's suggestion that the meaning of a sign is 'the translation of the sign into another system of signs' (CP 4.127) or 'the meaning of a sign is the sign it has to be translated into' (CP 4.132) might be considered exaggerated by some researchers but has a critical import for translation studies. ${ }^{1}$ Eco $(2001,70)$ aptly remarks that 'even though Peirce never worked on translation from language to language ex professo he nonetheless did not fail to notice the specificity of this phenomenon with respect to the many other modes of interpretation'. The semiotic approach to translation has much to gain from Bakhtin's dialogism, as well. Torop (2002: 598) argues that although Bakhtin never directly addressed the problems of translation - as Peirce did - scholars still find reasons to connect him to issues of translation.

Closing our introductory note, we would like to thank the editors of Punctum for their invitation to edit the present volume and all external reviewers for their contribution and thoughtful comments. We strongly believe that translation studies and semiotics share a common field of research. They both search for a signification that is the result of the interaction and synergy of semiotic systems, and that, in its turn, can not be simply a matter of transferring signifiers, but of negotiating signifieds. We must always remember that the two fields, translation studies and semiotics, explore cultural expression and its transmutations, in other words, cultural communication.

\section{NOTES}

${ }^{1}$ We have to remember that for Jakobson (1977: 1029), 'one of the most felicitous, brilliant ideas which general linguistics and semiotics gained from the American thinker is his definition of meaning as "the translation of a sign into another system of signs"'.

\section{REFERENCES}

Baker, Mona 1992. In other words. A coursebook on translation. London and New York: Routledge. Barthes, Roland 1964. La rhétorique de l'image. Communications 4: 40-51. 
Bassnett, Susan 1980. Translation Studies. London and New York: Methuen.

Díaz-Cintas, Jorge and Aline Remael 2007. Audiovisual Translation, Subtitling. London and New York: Routledge.

Eco, Umberto 1976. A Theory of Semiotics. Bloomington: Indiana University Press.

Eco, Umberto 2001. Experiences in Translation. Trans. Alastair McEwen, Toronto, Buffalo, London: University of Toronto Press.

Groupe $\mu$ 1992. Traité du signe visuel. Pour une rhétorique de l'image. Paris: Le Seuil.

Hatim, Basil and Ian Mason 1990. Discourse Analysis and the Translator. London: Logman.

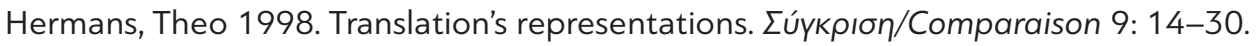

Jakobson, Roman 1959. On Linguistic Aspects of Translation. In: Reuben A. Brower (ed.), On Translation. Cambridge, MA: Harvard University Press, 232-239.

Jakobson, Roman 1977. A Few Remarks on Peirce, Pathfinder in the Science of Language. Modern Language Notes 92: 1026-1932.

Kress, Gunther and Theo van Leeuwen 2006. Multimodal Discourse. London: Bloomsbury Academic. Kress, Gunther and Theo van Leeuwen 2006 [1996]. Reading Images. The Grammar of Visual Design. London and New York: Routledge.

Larsen, Tord 1987. Action, morality and cultural translation. Journal of Anthropological Research 43 (1): 1-28.

Lotman, Juri 1990. Universe of the Mind. A Semiotic Theory of Culture. Indiana University Press: Bloomington and Indianapolis.

Munday, Jeremy 2004. Advertising: some challenges to translation theory. The Translator 10 (2): 199219.

Pálsson, Gísli 1994. Introduction: Beyond Boundaries. In: Gísli Pálsson (ed.), Beyond Boundaries: Understanding, Translation and Anthropological Discourse. Oxford and Providence: Berg, 1-40.

Peirce, Charles Sanders 1931-1958. Collected Papers of Charles Sanders Peirce (i 1866-1913). Vols. I-VI, Charles Hartshorne and Paul Weiss (eds.), 1931-1935, Vols. VII-VIII, Arthur W. Burks (ed.), 1958. Cambridge (Mass.): The Belknap Press, Harvard University Press. [In the text referred to as CP followed by volume and paragraph number].

Petrilli, Susan and Augusto Ponzio 2012. Iconicity, Otherness and Translation. Chinese Semiotic Studies 7 (1): 11-26.

Stecconi, Ubaldo 2009. Semiotics. In: Mona Baker and Gabriela Saldanha (eds.), Routledge Encyclopedia of Translation Studies. London and New York: Routledge, 260-263.

Torop Peeter 2002. Translation as translating as culture. Sign Systems Studies 30 (2): 593-605.

Torop, Peeter 2008. Translation and semiotics. Sign Systems Studies 36 (2): 253-257.

Evangelos Kourdis is Assistant Professor of Translation Semiotics in the Department of French Language and Literature, Aristotle University of Thessaloniki.

Email: ekourdis@frl.auth.gr

Pirjo Kukkonen is Professor of Swedish Translation Studies at the Department of Finnish, Finno-Ugrian and Scandinavian Studies, University of Helsinki.

Email: pirjo.kukkonen@helsinki.fi 